\title{
Peradilan Pajak dan Kepastian Hukum di tengah Globalisasi Ekonomi
}

\author{
Tjip Ismail \\ Pengadilan Pajak, Bidang Yudisial Departemen Keuangan RI \\ Jl. Dr. Wahidin No.1 Gedung D. Lt. V - Jakarta \\ tjip@cbn.net.id
}

\begin{abstract}
This research discusses the problem of legal certainty in economic globalization and tax court as legal enforcement instrument and tax dispute settlement through tax court. This research uses qualitative research method which secondary data is legal source. Using this method, this research found: First, tax court might be an important instrument in the effort of creating legal certainty; Second, tax court is a court under Supreme Court which exercise court (kehakiman) power in the matter of taxation; Third, tax dispute is a dispute in the matter of taxation between subject of tax (wajib pajak) and government official which has authority in taxation.
\end{abstract}

Key word : Tax court, legal certainty, economic globalization.

\begin{abstract}
Abstrak
Penelitian ini mengkaji permasalahan kepastian hukum di dalam globalisasi ekonomi dan pengadilan pajak sebagai instrumen penegakan hukum serta penyelesaian sengketa pajak melalui pengadilan pajak. Penelitian menggunakan metode penelitian kualitatif dengan menggunakan data sekunder berupa bahan hukum. Dengan metode penelitian tersebut, penelitian menemukan: Pertama, pengadilan pajak dapat menjadi instrumen penting dalam upaya menciptakan kepastian hukum. Kedua, pengadilan pajak adalah lingkungan peradilan di bawah Mahkamah Agung yang melaksanakan kekuasaan kehakiman di bidang perpajakan. Ketiga, sengketa pajak adalah sengketa di bidang perpajakan antara wajib pajak dan pejabat yang berwenangdi bidang perpajakan.
\end{abstract}

Kata kunci : Peradilan pajak, kepastian hukum, globalisasi ekonomi 


\section{Pendahuluan}

Perkembangan teknologi informasi telah membawa banyak dampak. Kemajuan di bidang telekomunikasi berhasil menghubungkan manusia tanpa menyisakan jarak dan waktu sedikitpun. Manusia dapat saling berkomunikasi meski pada saat bersamaan berada di tempat yang sangat berjauhan. Produsen di Asia bisa langsung melakukan negosiasi dengan distributor dan konsumen di Eropa, seorang penulis di Afrika dapat langsung mengirimkan draft bukunya kepada penerbit di Amerika dalam waktu kurang dari satu menit, seorang kepala negara di Timur Tengah bisa langsung menghubungi sejawatnya di Australia.

Begitupun dengan tingkat kecepatan transaksi bisnis. Seorang importir dengan cepat dan mudah bisa langsung melakukan pembayaran kepada eksportir tanpa harus bertemu secara fisik. Cukup dengan menelepon pihak bank atau dengan memanfaatkan fasilitas e-banking yang sudah populer di kalangan perbankan, uang bisa segera berpindah dari rekening importir ke rekening eksportir.

Kemajuan teknologi informasi ini telah menghilangkan batas-batas fisik, termasuk batas geografis negara. Masyarakat dunia dengan mudah bisa saling mengenal dan menjalin kerjasama lewat dunia maya. Dunia telah menjadi apa yang disebut para cendekiawan sebagai kampung global (global village). ${ }^{1}$

Globalisasi mempermudah para pelaku bisnis/usaha dalam melakukan kegiatan usahanya. Mereka secara leluasa dapat memilih dan menentukan lokasi usaha tidak hanya dalam satu negara tetapi juga di berbagai negara. Dengan beragam alasan, para pebisnis dapat menentukan dimana dan berapa banyak uang yang akan diinvestasikan. Namun demikian, alasan utama dari para pebisnis ini biasanya adalah tempat mana atau siapa yang paling mampu memberikan jaminan keamanan dan kepastian hukum sehingga potensi keuntungan lebih bisa diukur dan diprediksi.

Pemerintah di suatu negara berkepentingan untuk memperoleh dukungan dari masyarakatnya. Demi mencapai tujuan itu, mereka berupaya keras memenangkan hati masyarakat. Caranya bisa berbagai macam, antara lain membuka lapangan pekerjaan, memberikan fasilitas layanan pendidikan dan kesehatan yang memadai

${ }^{1}$ Istilah global village dipopulerkan oleh Marshal McLuhan melalui dua bukunya yang berjudul The Gutenberg Galaxy: The Making of Typographic Man yang terbit tahun 1962 dan Understanding Media yang terbit tahun 1964. Istilah itu ia gunakan untuk menggambarkan dunia yang 'mengkerut' menjadi sebuah kampung sebagai akibat dari teknologi elektrik dan pergerakan informasi yang sangat cepat dari satu tempat ke tempat lainnya. Tentang hal ini bisa juga dilihat di http:/ /en.wikipedia.org/Wiki/Global_village_(term) 
dan berkualitas, menciptakan stabilitas politik dan keamanan, serta meningkatkan taraf hidup masyarakat.

Pemerintah memerlukan dukungan para pebisnis untuk mempercepat pencapaian tujuan itu. Pebisnis memiliki kemampuan untuk mengadakan lapangan pekerjaan dan menyediakan barang kebutuhan masyarakat. Namun demikian, di sisi lain pebisnis juga membutuhkan sejumlah kondisi untuk mendukung kegiatan usahanya. Kondisi tersebut antara lain adalah regulasi yang bersahabat, keamanan yang terjamin, dan fasilitas pendukung kemudahan usaha lainnya.

Globalisasi, selain mengandung peluang, berpotensi menghadirkan ancamanancaman baru bagi para pelaku usaha. Menipisnya peran negara dan mengaburnya batas-batas geografis antarnegara berpeluang menghadirkan banyak bentuk sengketa baru baik sengketa antarpelaku maupun antara pelaku usaha dengan pemerintah.

Terkait dengan hal tersebut di atas, diperlukan institusi yang mampu menjamin bahwa setiap bentuk sengketa dapat benar-benar diselesaikan melalui mekanisme yang jelas dan terukur. Dalam konteks ini, institusi pengadilan pajak merupakan jawaban atas tuntutan kebutuhan kelembagaan tersebut khususnya yang berhubungan dengan penyelesaian sengketa pajak yang terjadi antara wajib pajak dengan pemungut pajak (pemerintah).

\section{Rumusan Masalah}

Dari uraian di atas dapat dirumuskan apa urgensi pengadilan pajak sebagai instrumen penegakan hukum di bidang perpajakan.

\section{Tujuan Penelitian}

Penelitian ini bertujuan untuk mengetahui urgensi pengadilan pajak sebagai instrumen penegakan hukum di bidang perpajakan.

\section{Metode Penelitian}

Dalam melakukan penelitian ini peneliti menggunakan metode penelitian kualitatif dimana penelitian tidak mengandalkan bukti berdasarkan logika matimatis, prinsip angka atau metode statistik. ${ }^{2}$ Berkaitan dengan bahasan "kerugian negara",

${ }^{2}$ Deddy Mulyana, Metodologi Penelitian Kualitatif Paradigma Baru Il,mu Komunikasi dan Ilmu Sosial Lainya, PT Premaja Rosdakarya Bandung 2001, hlm. 150 
penulis melakukan pendekatan satute approach yaitu mendalami makna dari undangundang perpajakan utamanya undang-undang Ketentuan Umum dan Tatacara Perpajakan ${ }^{3}$ yang mengatur khusus ikhwal kerugian negara sebagai lex specialis terhadap pengaturan lainnya.

Namun demikian, karena tidak ada peraturan perundangan yang dapat mengatur dengan selengkap-lengkapnya dan jelas-sejelasnya, maka tidak mungkin ada suatu peraturan perundang-undangan mengatur dan mencakup seluruh kegiatan kehidupan manusia, ${ }^{4}$ diperlukan penunjang undang-undang. Sebagai penunjang penentuan hipotesa penelitian tersebut, dilakukan dengan pendekaan comperative approach terhadap undang-undang lainnnya yang mengatur ketentuan dan mekanisme hingga dapat menimbulkan kerugian negara yaitu dari undang-undang Pemberantasan Tindak Pidana Korupsi. ${ }^{5}$

Undang-undang Keuangan Negara, ${ }^{6}$ undang-undang Perbendahara-an Negara ${ }^{7}$ dan undang-undang lainnya. Sementara itu, pendekatan case approach, historical approach dan conseptual approach tidak digunakan, semata karena alasan efisiensi waktu semata.

Data yang dipergunakan dalam penelitian ini diperoleh dari bahan pustaka (secondary data) yang bersifat publik, yaitu mencakup dokumen-dokumen resmi, buku-buku hasil penelitian yang berwujud laporan, ${ }^{8}$ khususnya berupa batas pengaturan dalam undang-undang. Karena undang-undang merupakan sumber utama dalam penentuan suatu kebijakan publik, sebagaimna dianut dalam herarki per undangan di Indonesia bahwa ketentuaan peraturan perundang-undangan yang lebih rendah tidak boleh bertentangan dengan ketentuaan perundangudangan di atasnya. ${ }^{9}$

Akan tetapi memprioritaskan salah satu undang-undang sebagai sumber utama dalam penelitian yaitu undang-undang Perpajakan, karena kedudukan undangundang tersebut sebagai lex specialis legi generale. Sehingga kedudukan undangundang yang baru akan menafikan undang-undang lama sebagaimana adagium dalam hukum yang dianut lex posterior derogate legi priori akan diabaikan.

${ }^{3}$ UU No. 6 Tahun 1983 juncto UU No. 16 Tahun 2009

${ }^{4}$ Sudikno Mertokusumo, Penemuan Hukum Sebuah Pengantar, Liberty Yogyakarta 2001, hlm. 48

${ }^{5}$ UU No. 31 Tahun 1999 juncto UU NO. 20 Tahun 2001

${ }^{6}$ UU No. 17 Tahun 2003

${ }^{7}$ UU No. 1 Tahun 2004

${ }^{8}$ Soerjono Soekanto, Pengantar Penelitian Hulkum, Universitas Indonesia, Jakarta, 1984, hlm. 16

${ }^{9}$ UU 10 Tahun 2004 tentang Pembentukan Peraturan Per Undang-undangan, Ps. 7 mengatur tentang hirearki peraturan per UUan yaitu UUD 1945, UU/Peratruan Pengganti UU, Peraturan Pemerintah, Peraturan Presiden dan Peraturan Daerah. 
Dengan demikian dalam penelitian ini penwliti lebih mengutamakan pada undang-undang Perpajakan sebagai sumber utama penelitian, khususnya berkaitan dengan mekanisme dan historis self assessment sebagai sistem perpajakan yang dianut di Indonesia, ketetapan pajak ketika self assessment titdak dipatuhi hingga timbulnya kerugian negara sebagai akumulasi proses tersebut.

Pengolahan dan analisis data yang digunakan adalah diskriptif kualitatif. Pengolahan data pada hakikatnya merupakan kegiatan untuk mengadakan sistematisasi terhadap bahan-bahan hukum. Sistematisasi berarti membuat klasifikasi terhadap bahanbahan hukum tersebut untuk memudahkan pekerjaan analisis dan konstruksi. ${ }^{10}$

\section{Hasil dan Pembahasan}

Pemerintah berwenang melakukan pungutan pajak demi membiayai pembangunan. Dana yang dihimpun digunakan untuk membiayai kegiatan-kegiatan yang berhubungan baik langsung maupun tidak langsung dengan kepentingan dan kebutuhan masyarakat. Untuk alasan ini pula, pemerintah menetapkan pajak tertentu bagi siapa saja, termasuk pebisnis, yang dinilai pantas untuk ditetapkan sebagai wajib pajak.

Dalam konteks global, pendapatan yang diperoleh dari pajak sangat berguna bagi pemerintah untuk memperkuat kemampuan mempertahankan diri dan mengambil keuntungan dari globalisasi ekonomi. Atas dasar itu, tidak bisa dipungkiri bahwa pajak berperan penting dalam pembangunan.

Pajak berperan penting dalam pembangunan karena dua fungsi yang melekat padanya, yakni fungsi budgeter dan fungsi regulerend. Fungsi budgeter pajak adalah mengisi kas negara dalam rangka melancarkan roda pemerintahan dengan cara mengumpulkan uang sebanyak-banyaknya sesuai dengan undang-undang yang berlaku yang pada waktunya akan digunakan untuk membiayai pengeluaranpengeluaran negara, yaitu pengeluaran rutin dan pengeluaran pembangunan, dan jika ada sisa (surplus) akan digunakan sebagai tabungan pemerintah. Sedangkan fungsi regulerend adalah fungsi yang dapat dimanfaatkan oleh pemerintah untuk menopang usaha pemerintah di bidang ekonomi, sosial, dan budaya sesuai yang telah ditetapkan dalam program pembangunan. ${ }^{11}$ Termasuk didalamnya mengatur atau melaksanakan kebijakan di bidang sosial dan ekonomi.

\footnotetext{
${ }^{10}$ Soerjono Soekanto, Pengantar Penelitian Hukum, UI Press, Jakarta, 1986, hlm. 251-252.

${ }^{11}$ B. Boediono, Perpajakan Indonesia, Jilid I, Jakarta, Kawula Indonesia, 1996.
} 
Selain itu, pajak berperan penting karena kontribusinya yang sangat dominan dalam mendukung Anggaran Pendapatan dan Belanja Negara (APBN). Departemen Keuangan mencatat bahwa kontribusi pajak terhadap APBN terus mengalami peningkatan dari tahun ke tahun. Sebelum tahun 2000, kontribusi pajak hanya berada pada kisaran 55-60\% (lima puluh lima sampai enam puluh persen). Kini pajak menjadi sumber pemasukan utama bagi anggaran pendapatan dan belanja negara. Pada APBN 2008, pajak memberikan kontribusi 73,1\% (tujuh puluh tiga koma satu persen) dari total penerimaan negara atau Rp 609,22 (enam ratus sembilan triliun dua puluh dua milyar rupiah). Tahun berikutnya, yakni APBN 2009, pendapatan perpajakan diharapkan menyumbang sebesar 725,8 (tujuh ratus dua puluh lima triliun delapan milyar) atau 70\% (tujuh puluh persen) terhadap belanja negara yang angkanya mencapai 1.037,1 (satu trilyun tiga puluh tujuh milyar satu juta rupiah. ${ }^{12}$

Pajak juga menjadi penting karena sifatnya yang executorial. Sifatnya yang mempunyai kekuatan hukum tetap memudahkan pemerintah mengidentifikasi, menginventarisir, dan menghimpun pajak tanpa dibayangi keraguan. Selain itu, pemerintah juga dapat lebih mudah mengukur dan menghitung potensi penerimaan dari pajak. Sifat executorial pajak ditetapkan antara lain oleh UU No. 28 Tahun $2007^{13}$ yang menyebutkan bahwa Surat Tagihan Pajak (STP), Surat Ketetapan Pajak Kurang Bayar (SKPKB), Surat Ketetapan Pajak Kurang Bayar Tambahan (SKPKBT) harus dilunasi dalam jangka waktu 1 bulan sejak tanggal diterbitkan; dan oleh Pasal 25 ayat (7) dan Pasal 27 ayat (5) UU No. 28 tahun 2007 yang menyatakan bahwa dalam hal wajib pajak mengajukan Keberatan atau Banding maka jangka waktu pelunasan pajak tertangguhnya adalah sampai dengan 1 bulan sejak tanggal penerbitan SK keberatan/banding.

Alasan lain mengapa pajak sangat penting adalah bahwa pajak tidak hanya sekedar kewajiban tetapi lebih merupakan hak warga negara untuk ikut berpartisipasi dalam pembangunan. Pajak yang dibayarkan oleh warga negara digunakan untuk membiayai program-program pembangunan baik di pusat maupun di daerah. Dengan demikian, manfaat dari pajak juga akan diterima kembali oleh warga negara yang menjadi wajib pajak dalam bentuk lain seperti fasilitas layanan umum dan lain sebagainya. Selain itu, adanya ketentuan Undang-undang yang menyatakan bahwa penerimaan pajak penghasilan (PPh), Perseorangan, PPh. Karyawan dan pajak bumi

\footnotetext{
${ }^{12}$ www.fiskal.depkeu.go.id

${ }^{13}$ Pasal 9 ayat (3) UU Nomor 6 Tahun 1983 tentang Ketentuan Umum dan Tata Cara Perpajakan sebagaimana telah diubah terakhir dengan UU Nomor 28 Tahun 2007
} 
dan bangunan (PBB) dibagihasilkan kepada Daerah turut memperkuat komitmen pemerintah untuk memberikan manfaat pajak kepada para wajib pajak secara langsung.

Kemampuan pemerintah dalam menghimpun pajak memiliki pengaruh terhadap kemampuan pemerintah untuk bersaing dalam rangka mempertahankan diri dan mengambil keuntungan dari globalisasi ekonomi. Kontribusi signifikan pajak terhadap APBN dapat mengeliminasi opsi mengadakan pinjaman negara untuk menutup kebutuhan pembiayaan pembangunan. Pemerintah Indonesia pernah menggantungkan pembiayaan pembangunannya kepada pinjaman luar negeri. Akibatnya, Indonesia harus menanggung sejumlah konsekuensi baik politik maupun ekonomi.

Kemampuan pemerintah untuk secara mandiri membiayai kegiatan pembangunan juga dapat meningkatkan independensinya dalam menentukan arah kebijakan ekonomi dan politiknya. Kondisi itu dimungkinkan mengingat tiadanya beban dibanding saat tersandera oleh hutang. Dalam situasi yang demikian, pemerintah punya kebebasan dan keleluasaan untuk merancang kebijakannya sendiri dan melandasinya semata-mata demi kesejahteraan masyarakat seluas-luasnya.

Berdasarkan pemikiran di atas sangat jelas bagaimana pajak dapat meningkatkan kemampuan sebuah negara/pemerintahan untuk bertahan dan mengambil keuntungan dari globalisasi ekonomi yang tak terelakkan.

\section{Globalisasi Ekonomi dan Kepastian Hukum}

Untuk memahami globalisasi ekonomi, terlebih dahulu perlu dipahami apa yang dimaksud dengan globalisasi. Anthony Giddens mendefinisikan globalisasi sebagai intensifikasi hubungan sosial tingkat dunia yang mempertemukan berbagai tempat (lokalitas) sedemikian rupa sehingga kejadian-kejadian yang terjadi di suatu daerah dipengaruhi oleh peristiwa-peristiwa yang berlangsung di tempat-tempat yang sangat jauh dan demikian pula sebaliknya. ${ }^{14}$

Jan Aart Scholtc, sebagaimana dikutip Amien Rais, secara luas menggambarkan definisi globalisasi sebagai internasionalisasi, liberalisasi, universalisasi, westernisasi/ modernisasi, dan deteritorialisasi. ${ }^{15}$

\footnotetext{
${ }^{14}$ www.infed.org/biblio/defining-globalization.htm

${ }^{15}$ M. Amien Rais, Agenda Mendesak Bangsa Selamatkan Indonesia, PPSK Press, Yogyakarta, 2008, hlm. 13-14
} 
Globalisasi sebagai internasionalisasi dimaknai sebagai kegiatan antar negara yang melampaui batas wilayah masing-masing sehingga terjadi saling tukar dan saling ketergantungan internasional, terutama menyangkut modal dan perdagangan. Globalisasi sebagai liberalisasi merujuk pada proses pemusnahan berbagai restriksi politik sehingga ekonomi dunia menjadi lebih terbuka dan tanpa batas.

Makna universalisasi dari globalisasi adalah universalisasi informasi, komunikasi dan transportasi, dan berbagai kegiatan masyarakat dunia lainnya. Sementara globalisasi sebagai westernisasi/modernisasi dimaksudkan sebagai merebaknya struktur modernitas barat ke seluruh dunia. Struktur modernitas barat tersebut adalah kapitalisme, rasionalisme, industrialisme, birokratisme, dan lain sebagainya yang cenderung merusak budaya lokal yang sudah ada lebih dulu.

Terakhir, globalisasi juga mempunyai makna deteritorialisasi, yakni terjadinya rekonfigurasi geografi, sehingga ruang sosial tidak lagi dipetakan berdasarkan peta teritorial, jarak, dan batas teritorial.

Dari pengertian globalisasi di atas dapat dikatakan bahwa globalisasi ekonomi bisa dinyatakan sebagai proses sharing kegiatan ekonomi dunia yang berjalan melanda semua masyarakat di berbagai negara dengan mengambil 3 bentuk kegiatan, yaitu perdagangan internasional, investasi asing langsung dan aliran pasar modal. ${ }^{16}$

Globalisasi ekonomi, menurut Tulus Tambunan, dapat diartikan sebagai suatu proses dimana semakin banyak negara yang terlibat dalam kegiatan ekonomi dunia. ${ }^{17}$ Ia menambahkan bahwa jika pada periode sejak perang dunia kedua berakhir hingga tahun 1970-an ekonomi dunia didominasi oleh ekonomi Amerika Serikat (AS), sekarang ini walaupun produk domestik bruto (PDB) AS masih besar yakni sekitar 45\% (empat puluh lima persen) dari PDB dunia, peran dari ekonomi Uni Eropa, Jepang dan negaranegara yang tergolong dalam newly industrialized countries (NICs), seperti Korea Selatan, Taiwan, dan Singapura, dan Cina jauh lebih kuat sebagai motor penggerak perekonomian dunia. Semakin mengglobalnya suatu negara di dalam perekonomian dunia dapat dilihat dari misalnya peningkatan perdagangan internasionalnya (ekspor dan impor) yang tercermin antara lain pada peningkatan pangsa ekspornya di pasar global dan peningkatan rasio impornya terhadap PDB.

\footnotetext{
${ }^{16}$ www.worldbank.org/economic policy/globalization/ag 01.htm, The World Bank Group, Globalization

17 Tulus Tambunan, Implikasi dari Globalisasi/Perdagangan Bebas Dunia terhadap Ekonomi Nasional, Makalah disampaikan dalam Seminar Penataan Ruang dan Pengembangan Wilayah, Dep.PU, Jakarta, 1 Juli 2005
} 
Tulus Tambunan selanjutnya menjelaskan bahwa proses globalisasi dari sisi ekonomi adalah suatu perubahan di dalam perekonomian dunia yang bersifat mendasar atau struktural dan akan berlangsung terus dalam laju yang semakin pesat mengikuti kemajuan teknologi yang juga prosesnya semakin cepat. Perkembangan ini telah meningkatkan kadar hubungan saling ketergantungan dan juga mempertajam persaingan antarnegara, tidak hanya dalam perdagangan internasional tetapi juga dalam kegiatan investasi, finansial dan produksi. ${ }^{18}$

Globalisasi ekonomi ditandai dengan semakin menipisnya batas-batas geografi dari kegiatan ekonomi atau pasar secara nasional atau regional di satu sisi, sementara di sisi yang lain negara-negara yang ada semakin mengglobal menjadi "satu". 19

Globalisasi ekonomi biasanya dikaitkan dengan proses internasionalisasi produksi, perdagangan dan pasar uang. Globalisasi ekonomi merupakan suatu proses yang berada diluar pengaruh atau jangkauan kontrol pemerintah, karena proses tersebut terutama digerakkan oleh kekuatan pasar global, bukan oleh kebijakan atau peraturan yang dikeluarkan oleh sebuah pemerintah secara individu.

Menipisnya batas-batas geografi dan kedaulatan suatu pemerintahan negara muncul disebabkan oleh banyak hal, yang diantaranya menurut Halwani adalah komunikasi dan transportasi yang semakin canggih dan murah, lalu lintas devisa yang semakin bebas, ekonomi negara yang semakin terbuka, penggunaan secara penuh keunggulan komparatif dan keunggulan kompetitif tiap-tiap negara, metode produksi dan perakitan dengan organisasi manajemen yang semakin efisien, dan semakin pesatnya perkembangan perusahaan multinasional di hampir seantero dunia. Selain itu, penyebab-penyebab lainnya adalah semakin banyaknya industri yang bersifat footloose akibat kemajuan teknologi (yang mengurangi pemakaian sumber daya alam), semakin tingginya pendapatan dunia rata-rata per kapita, semakin majunya tingkat pendidikan mayarakat dunia, ilmu pengetahuan dan teknologi di semua bidang, dan semakin banyaknya jumlah penduduk dunia. ${ }^{20}$

Globalisasi berjalan begitu cepat, menurut Tambunan, karena didukung oleh empat faktor; kemajuan ilmu pengetahuan dan teknologi, semakin terbukanya sistem perekonomian negara-negara di dunia baik dalam perdagangan, produksi, maupun

\footnotetext{
${ }^{18}$ Ibid.

${ }^{19}$ Ibid.

${ }^{20}$ R. Hendra Halwani, Ekonomi InternasionalD dan Globalisasi Ekonomi, Ghalia Indonesia, Jakarta, 2002, hlm. 365-367
} 
investasi/keuangan, mengglobalnya pasar finansial, dan semakin besarnya keinginan orang untuk bepergian keluar negeri. ${ }^{21}$

Terkait peran dari kemajuan teknologi terhadap proses globalisasi, Friedman menyatakan:

era globalisasi dibangun seputar jatuhnya biaya telekomunikasi - berkat adanya mikrochip, satelit, serat optik dan internet/Teknologi informasi yang baru ini mampu merajut dunia bersama-sama bahkan menjadi lebih erat. ...Teknologi ini juga dapat memungkinkan perusahaan untuk menempatkan lokasi bagian produksi di negara yang berbeda, bagian riset dan pemasaran di negara yang berbeda, tetapi dapat mengikat mereka bersama melalui komputer dan komperensi jarak jauh seakan mereka berada disatu tempat. Demikian juga berkat kombinasi antara komputer dan telekomunikasi yang murah, masyarakat sekarang dapat menawarkan pelayanan perdagangan secara global - dari konsultasi medis sampai penulisan data perangkat lunak ke proses data pelayanan yang sesungguhnya tidak pernah dapat diperdagangkan sebelumnya. ${ }^{22}$

Mengenai faktor pendorong kedua, yakni sistem perekonomian negara-negara di dunia yang semakin terbuka baik dalam perdagangan, produksi maupun investasi/keuangan, Friedman mengatakan:

Ide dibelakang globalisasi yang mengendalikannya adalah kapitalisme bebas semakin Anda membiarkan kekuatan pasar berkuasa dan semakin Anda membuka perekonomian Anda bagi perdagangan bebas dan kompetisi, perekonomian Anda akan semakin efisien dan berkembang pesat. Globalisasi berarti penyebaran kapitalisme pasar bebas ke setiap negara di dunia. Karenanya globalisasi juga memiliki aturan perekonomian tersendiri - peraturan yang bergulir seputar pembukaan, deregulasi, privatisasi perekonomian Anda, guna membuatnya lebih kompetitif dan atraktif bagi investasi luar negeri. ${ }^{23}$

Semakin terbukanya ekonomi suatu negara, menurut Tambunan, dapat dilihat dari perkembangan atas sejumlah indikator, antara lain adalah peningkatan rasio perdagangan luar negerinya (ekspor dan impor) terhadap PDBnya, semakin pentingnya peran dari perusahaan-perusahaan multinasional dalam kegiatan produksi di dalam negeri, dan semakin besarnya rasio investasi asing atau arus modal dari luar terhadap investasi total di dalam negeri. Atau, dilihat pada skala dunia adalah peningkatan rasio perdagangan dunia terhadap PDB dunia, rasio produksi dari perusahaan-perusahaan multinasional terhadap

\footnotetext{
${ }^{21}$ Tulus Tambunan, Op.Cit., hlm. 5-10

${ }^{22}$ Thomas L. Friedman, Memahami Globalisasi. Lexus dan Pohon Zaitun, Penerbit ITB, Bandung, 2002, hlm. 8

${ }^{23}$ Ibid., hlm. 9
} 
produksi dunia total, dan rasio arus modal antarnegara terhadap pembentukan modal dunia. ${ }^{24}$

Faktor pendorong ketiga adalah mengglobalnya pasar finansial yang prosesnya berlangsung berbarengan dengan keterbukaan ekonomi dari negara-negara di dunia dan penerapan sistem perdagangan bebas dunia. Kondisi ini memicu negara-negara didunia untuk bersaing dalam hal investasi dan keuangan. Semakin mengglobalnya pasar finansial tercerminkan oleh semakin besarnya sumber-sumber eksternal dalam pembiayaan kegiatan-kegiatan ekonomi domestik di banyak negara, tidak hanya di kelompok negara-negara maju tetapi juga di negara-negara sedang berkembang. Juga perkembangan pasar saham (modal) mencerminkan perubahan tersebut: semakin banyak saham-saham dari perusahaan-perusahaan asing yang tercatat di dalam pasar bursa di suatu negara. Selain itu, semakin mengglobalnya pasar finansial dipicu oleh semakin maraknya perdagangan mata uang asing lintas negara.

Terakhir, derasnya globalisasi didorong oleh keinginan orang untuk melakukan perjalanan antarnegara atau pindah dari satu negara ke negara lain yang semakin besar, baik untuk tujuan bisnis maupun lainnya. Keinginan ini didorong oleh peningkatan pendapatan rata-rata masyarakat dunia ditambah dengan peningkatan kepadatan penduduk di suatu wilayah/negara, dan kemajuan teknologi yang memungkinkan terjadinya mobilisasi orang antarnegara secara lebih cepat, aman dan lebih murah.

Persaingan antarnegara yang semakin ketat sebagai dampak dari globalisasi mengharuskan pemerintah untuk terus meningkatkan daya saing (competitiveness). Untuk itu, pemerintah perlu menyediakan semua perangkat pendukung yang dibutuhkan seperti stabilitas politik dan keamanan, regulasi yang ramah, dan kepastian hukum yang terjamin.

Pada konteks ini, pengadilan pajak berpeluang menjadi instrumen penting dalam upaya menciptakan kepastian hukum, khususnya yang berkaitan langsung dengan aktivitas bisnis/ perekonomian. Dengan kewenangan yang dimilikinya, pengadilan pajak dapat menjadi rujukan bagi para pelaku ekonomi untuk menyusun rencana dan tindakan bisnisnya.

${ }^{24}$ Tulus Tambunan, Implikasi Dari Globalisasi/Perdagangan Bebas Dunia Terhadap Ekonomi Nasional, Makalah disampaikan dalam Seminar Penataan Ruang dan Pengembangan Wilayah, Dep.PU, Jakarta, 1 Juli 2005, hlm. 7 


\section{Pengadilan Pajak sebagai Instrumen Penegakan Hukum}

Pada dasarnya setiap kegiatan atau aktivitas manusia perlu diatur oleh suatu instrumen yang disebut sebagai hukum. Hukum yang dimaksud adalah perundangundangan yang dibuat dan dilaksanakan oleh negara. ${ }^{25}$ Penegakan hukum yang berwibawa akan dapat menjamin terpeliharanya kepastian dan keadilan. ${ }^{26}$ Hukum bagaimanapun sangat dibutuhkan untuk mengatur kehidupan bermasyarakat di dalam segala aspeknya, baik dalam kehidupan sosial, politik, budaya, pendidikan, dan yang tak kalah penting adalah fungsinya atau peranannya dalam mengatur kegiatan ekonomi. Dalam kegiatan ekonomi inilah justru hukum sangat diperlukan karena sumber-sumber ekonomi yang terbatas disatu pihak dan tidak terbatasnya permintaan atau kebutuhan akan sumber ekonomi dilain pihak, sehingga konflik antara sesama warga dalam memperebutkan sumber-sumber ekonomi tersebut akan sering terjadi. ${ }^{27}$

Globalisasi ekonomi menuntut pemerintah suatu negara untuk terus meningkatkan daya saing. Salah satu caranya adalah dengan memberikan kepastian hukum yang menyangkut aktivitas perekonomian. Hukum yang dapat mendukung kehidupan ekonomi, menurut Max Weber sebagaimana dikutip Frank, adalah hukum yang memiliki beberapa karakteristik, yakni: predictability, stability, fairness, education, special ability of the lawyer. ${ }^{28}$

Hukum akan mampu memfasilitasi kegiatan ekonomi jika hukum tersebut pertama, bisa memperkirakan persoalan yang akan timbul di masa yang akan datang dan memberikan gambaran mengenai langkah-langkah apa yang harus diambil, ketika masyarakat memasuki hubungan-hubungan ekonomi yang melampaui lingkungan sosial tradisional mereka. Kedua, hukum itu juga merupakan kesepakatan dari berbagai kepentingan. Karena ia merupakan hasil kesepakatan dari banyak kepentingan maka ia punya kemampuan untuk menciptakan stabilitas.

Ketiga, hukum yang mendukung kegiatan perekonomian adalah yang mempunyai karakter fairness (keadilan). Setiap orang diperlakukan sama dihadapan hukum. Selain itu, ada standar tertentu tentang mana yang dianggap adil dan mana yang dinilai

\footnotetext{
hlm. 27

${ }^{26}$ Muhammad Ryaas Rasyid, Makna Pemerintahan Tinjauan dari segi Etika dan Kepemimpinan, PT. Mutiara Sumber Widya Penabur Benih Kecerdasan, Jakarta, 2002, hlm. 13

${ }^{27}$ Gunarto Suhardi, Peranan Hukum Dalam Pembangunan Ekonomi, Universitas Atmajaya, Yogyakarta, 2002, hlm. v.

${ }^{28}$ Thomas N. Frank, The New Development, Can American Law and Legal Institution Help Developing Countries?, Wisconsin Law Review, 1989, hlm. 206
}

${ }^{25}$ Hikmahanto Juwana, Bunga Rampai Hukum Ekonomi dan Hukum Internasional, Lentera Hati, Jakarta, 2002, 
tidak adil. Ketiadaan standar tersebut, dalam banyak pengalaman, dapat menyebabkan delegitimisai terhadap pemerintah, yang pada fase berikutnya berdampak pada meningkatnya pelanggaran hukum sebagai akibat dari legitimasi yang merosot.

Karakter yang keempat, yakni pendidikan (education), mengandung arti bahwa hukum yang ada haruslah hukum yang masuk kategori pendidikan (tinggi). Maksudnya adalah bahwa hukum tersebut tidak hanya yang bersifat empirik tetapi juga substantif. Terakhir, hukum yang bersahabat dengan kehidupan ekonomi adalah hukum yang didukung oleh para pengacara yang mempunyai kemampuan yang baik dan profesional dalam melakukan pekerjaannya; tidak sekedar menjadi partner penguasa, tukang stempel atau seseorang yang hanya mengurus soal finansial saja.

Melengkapi kriteria yang diajukan Weber, J. D. Nyhart, seperti dikutip oleh Radjagukguk, mengatakan bahwa selain memiliki karakter predictability, education, dan accommodation, hukum juga harus mengandung prinsip-prinsip procedural capability, codification of goals, balance, definition and clarity of status, agar hukum tersebut mampu berperan dalam menggerakkan ekonomi. ${ }^{29}$

Kemampuan prosedural (procedural capability), menurut Budiman Ginting, adalah kemampuan prosedur yang diciptakan oleh suatu sistem hukum dalam menyelesaikan masalah yang dibawa kepadanya. Misalnya dalam mengatur peradilan tribunal (court of administratif tribunal), penyelesaian sengketa di luar pengadilan (alternative dispute resolution), dan penunjukan arbiter konsiliasi (conciliation) serta lembaga-lembaga yang berfungsi sama dalam penyelesaian sengketa. ${ }^{30}$

Codification of goals adalah bahwa hukum dibuat dengan tujuan untuk pembangunan negara, untuk kepentingan orang banyak, dan tidak sekedar untuk kepentingan sekelompok orang tertentu.

Selain procedural capability dan codification of goals, prinsip lainnya adalah balance. Artinya adalah bahwa hukum harus mampu menciptakan keseimbangan antara kepentingan investor, kepentingan negara, dan kepentingan masyarakat, dan keseimbangan antara kepentingan investor asing dan domestik.

Terakhir, hukum harus berperan dalam menentukan definisi dan status yang jelas (definition and clarity of status) mengenai segala sesuatu dari orang yang

${ }^{29}$ Erman Radjagukguk, Peranan Hukum dalam Pembangunan Ekonomi, Jilid 2, Universitas Indonesia, Jakarta, 1995, hlm. 365-367

${ }^{30}$ Budiman Ginting, "Kepastian Hukum dan Implikasinya terhadap Pertumbuhan Investasi di Indonesia”, Pidato Pengukuhan Jabatan Guru Besar Tetap dalam Bidang Ilmu Hukum Investasi pada Fakultas Hukum Universitas Sumatera Utara yang disampaikan pada 20 September 2008 
melakukan kegiatan investasi, dalam hal ini dapat berupa ketegasan definisi, pengaturan, dan status terhadap investor asing dan kegiatan-kegiatan yang mereka lakukan.

Serupa dengan Weber, Dhaniswara berpendapat bahwa iklim perekonomian suatu negara sangat tergantung pada sistem hukum yang mampu menciptakan kepastian hukum (legal certainty), keadilan (fairness), dan efisiensi (efficiency). ${ }^{31}$ Bagi investor asing, hukum dan undang-undang menjadi satu tolok ukur untuk menentukan kondusif tidaknya iklim investasi di suatu negara. Infrastruktur hukum bagi investor menjadi instrumen penting dalam menjamin investasi mereka. Hukum bagi mereka memberikan keamanan, certainty dan predictability atas investasi mereka. Semakin baik kondisi hukum dan undang-undang yang melindungi investasi mereka, semakin dianggap kondusif iklim investasi dari negara tersebut. ${ }^{32}$ Pengadilan pajak hadir demi memenuhi kebutuhan-kebutuhan tersebut diatas, yakni menciptakan kepastian hukum (legal certainty) dan keadilan (fairness).

Peradilan pajak adalah lingkungan peradilan di bawah Mahkamah Agung yang melaksanakan kekuasaan kehakiman bagi wajib pajak atau penanggung pajak yang mencari keadilan terhadap sengketa pajak.

Ide tentang lembaga semacam Peradilan Pajak itu sendiri sebenarnya telah dimulai sejak masa Pemerintahan Hindia Belanda dengan dibentuknya Raad van het Beroep voor Belastingzaken (Badan Banding Administrasi Pajak) berdasarkan Ordonansi 1915 (Staatsblad Nomor 707) yang kemudian diganti dengan Ordonansi 27 Januari 1927 (Staatsblad 1927) Nomor 29 tentang Peraturan Pertimbangan Urusan Pajak (Regeling van het Beroep in Belastingzaken). ${ }^{33}$

Selanjutnya, lembaga tersebut oleh UU Nomor 5 Tahun 1959 diubah menjadi Majelis Pertimbangan Pajak yang tugasnya memberi keputusan atas surat pemeriksaan banding tentang pajak-pajak negara dan pajak-pajak daerah. ${ }^{34}$ Berdasarkan UU Nomor 6 Tahun 1983, MPP diberlakukan sebagai badan peradilan pajak yang sah dan tidak bertentangan dengan kekuasaan kehakiman sebagaimana tercantum dalam UU Nomor

\footnotetext{
${ }^{31}$ Harjono K. Dhaniswara, Hukum Penanaman Modal: Tinjauan terbadap Pemberlakuan Undang-Undang Penanaman Modal, Raja Grafindo Persada, Jakarta, 2007, hlm. 8

${ }^{32}$ Hikmahanto Juwana, Arah Kebijakan Pembangunan Hukum di Bidang Perekonomian dan Investasi, dalam: Majalah Hukum Nasional, No. 1 Tahun 2007, BPHN, Departemen Hukum dan HAM RI, hlm. 71

33 Atep Adya Barata, Memahami Pengadilan Pajak "Meminimalisasi dan Menghindari Sengketa Pajak dan Bea Cukai”, Elex Media Komputindo, Jakarta, 2003, hlm. 5

${ }^{34}$ Nisa Istiani, Menelaah Keberadaan Pengadilan Pajak, tulisan bisa dilihat di http:/ /www.pemantauperadilan.com/ opini/21.MENELAAH\%20KEBERADAAN\%20PENGADILAN\%20PAJAK.pdf
} 
14 Tahun 1970. UU Nomor 6 Tahun 1983 mengatur hal ini dalam Pasal 27 ayat (1) yang berbunyi, “Wajib Pajak dapat mengajukan permohonan banding hanya kepada badan peradilan Pajak terhadap keputusan mengenai keberatannya yang ditetapkan oleh Direktorat Jenderal Pajak." Selanjutnya, ayat (2) pasal yang sama menyebutkan, "Sebelum badan peradilan pajak sebagaimana dimaksud pada ayat (1) dibentuk, permohonan banding diajukan kepada Majelis Pertimbangan Pajak, yang putusannya bukan merupakan keputusan Tata Usaha Negara".

Seiring meningkatnya dinamika perekonomian dan pembangunan nasional, tuntutan untuk memberikan pelayanan yang sederhana, cepat, dan murah kepada masyarakat juga turut meningkat. Berdasarkan hal tersebut, MPP dianggap sudah tidak memadai lagi untuk menyelesaikan sengketa pajak. Oleh sebab itu, pemerintah kemudian membentuk Badan Penyelesaian Sengketa Pajak (BPSP) melalui UndangUndang Nomor 17 Tahun 1997.

Dalam undang-undang tersebut ditentukan bahwa untuk mendapatkan keadilan pengenaan pajak, wajib pajak dapat menempuh jalur-jalur sebagai berikut:

a. Jalur keberatan pajak dan banding ke BPSP.

b. Jalur melalui Peradilan Tata Usaha Negara (PTUN).

c. Jalur melalui peradilan umum.

Undang-undang tersebut juga menyebutkan bahwa BPSP sebagai badan peradilan pajak hanya berwenang menyelesaikan sengketa administratif, yaitu dari segi perhitungan dan akuntansi, bukan mengenai pidana pajak.

Berikutnya, meskipun tidak bertentangan dengan UU Nomor 14 Tahun 1970, BPSP pada kenyataannya belum merupakan badan peradilan yang berpuncak di Mahkamah Agung. Oleh karena itu, dibutuhkan suatu pengadilan pajak yang sesuai dengan sistem kekuasaan kehakiman yang berlaku di Indonesia sekaligus mampu menciptakan keadilan dan kepastian hukum dalam penyelesaian sengketa pajak. Atas berbagai pertimbangan itulah Pemerintah Republik Indonesia mengesahkan Undang-Undang Nomor 14 Tahun 2002 tentang Pengadilan Pajak (UU Nomor 14 Tahun 2002). Definisi pengadilan pajak dijelaskan dalam Pasal 2, yaitu "Pengadilan Pajak adalah badan peradilan yang melaksanakan kekuasaan kehakiman bagi Wajib Pajak atau penanggung pajak yang mencari keadilan terhadap sengketa Pajak". Keberadaan Peradilan Pajak ini juga sejalan dengan Pasal 15 UU No. 4 Tahun 2004 tentang Kekuasaan Kehakiman yang menyebutkan bahwa "Pengadilan Khusus hanya dapat dibentuk dalam satu lingkungan peradilan". 
Menurut UU Nomor 14 Tahun 2002 tetang Pengadilan Pajak, pembinaan teknis peradilan bagi Pengadilan Pajak dilakukan oleh Mahkamah Agung. Sedangkan pembinaan organisasi, administrasi, dan keuangan dilakukan oleh Departemen Keuangan. Susunan Pengadilan Pajak terdiri atas: Pimpinan, Hakim Anggota, Sekretaris, dan Panitera. Pimpinan Pengadilan Pajak sendiri terdiri dari seorang Ketua dan sebanyak-banyaknya 5 orang Wakil Ketua.

Pengadilan pajak berkedudukan di ibu kota negara. Persidangan oleh Pengadilan pajak dilakukan di tempat kedudukannya, dan dapat pula dilakukan di tempat lain berdasarkan ketetapan ketua pengadilan pajak.

Pengadilan pajak memiliki kewenangan untuk memeriksa, memutus, dan mengadili sengketa pajak. Sengketa pajak itu sendiri terdiri dari sengketa pajak pusat dan sengketa pajak daerah. Termasuk pajak pusat adalah PPh, PPN dan PPNBM, PBB, BPHTB, bea materei, bea, dan cukai. Dari ketujuh macam pajak tersebut lima (5) yang pertama dikelola oleh Direktorat Jenderal Pajak, sedangkan dua lainnya ditangani oleh Direktorat Bea dan Cukai, sebagaimana diatur dalam UU Kepabeanan UU No. 10 Tahun 1995, dan UU Cukai No. 11 Tahun 1995.

Kehidupan berbangsa dan bernegara tidak bisa dilepaskan dari keberadaan konstitusi negara yang bersangkutan dengan memperhatikan peran dan fungsi konstitusi sebagai dasar dan acuan bagi penyelenggara negara untuk mencapai tujuan yang dicita-citakan. ${ }^{35}$ Keberadaan pengadilan pajak sangat penting dalam sistem hukum Indonesia dan perekonomian global terutama jika dikaitkan dengan peran pentingnya dalam penyelenggaraan pembangunan nasional. Pengadilan pajak memberikan kepastian hukum, menciptakan rasa keadilan, dan mendukung terselenggaranya pelayanan hukum yang sederhana, cepat, dan murah.

Berbeda dari nilai keputusan institusi-institusi yang pernah ada sebelumnya, keputusan pengadilan pajak merupakan keputusan akhir dan berkekuatan hukum tetap. Hal ini secara tegas dinyatakan dalam Pasal 77 ayat (1) UU No. 14 Tahun 2002 tentang Pengadilan Pajak. Berkekuatan hukum tetap itu berarti setara dengan putusan tingkat kasasi. Oleh karena itu, terhadap putusan pajak tidak bisa dilakukan banding atau kasasi.

Kepastian hukum itu tidak terjadi misalnya manakala UU Nomor 9 Tahun 1994 diberlakukan. Meskipun pada pasal 27 ayat (1) dinyatakan bawa wajib pajak dapat

${ }^{35}$ H.R.E. Kosasih Taruna Sepandji, MS, Konstitusi dan Kelembagaan Negara, Universal Offset, Bandung, 2002. 
mengajukan permohonan hanya kepada Badan Peradilan terhadap Keputusan mengenai keberatannya yang ditetapkan oleh Direktur Jenderal Pajak, pada praktiknya sebelum peradilan pajak tersebut dibentuk, permohonan banding tetap diajukan ke Majelis Pertimbangan Pajak (MPP) yang putusannya bukan merupakan keputusan tata usaha negara. Dengan kata lain, putusan itu tidak berkekuatan hukum tetap.

Keberadaan pengadilan pajak menjadi penting juga karena lembaga tersebut berada pada posisi di tengah antara wajib pajak dan pemungut pajak saat keduanya terlibat dalam sengketa pajak. Namun demikian, dengan kewenangan yang diberikan Undang-undang kepadanya, pengadilan pajak mempunyai otoritas untuk menjadi penyelesai masalah. Pengadilan pajak dapat berperan sebagai penengah yang bersifat independen, sehingga dengan demikian kedua belah pihak yang bersengketa dapat mempercayakan penyelesaian sengketa mereka kepadanya. Dengan demikian, harapan akan hadirnya keadilan di tengah sengketa dapat dipenuhi.

Selain itu, adanya pengadilan pajak dapat mendukung upaya peningkatan pelayanan publik yang sederhana, cepat, dan murah. Pengadilan pajak yang termasuk dalam kelompok pengadilan khusus sengaja dibentuk agar masyarakat yang secara khusus berselisih atas pajak dengan pemerintah dapat segera menyelesaikan permasalahannya dengan cepat dan murah. Akan berbeda situasinya jika tidak ada pengadilan pajak. Masyarakat pasti membutuhkan waktu dan biaya yang lebih besar mengingat banyaknya perkara yang diurus, misalnya oleh peradilan umum.

\section{Penyelesaian Sengketa melalui Pengadilan Pajak}

Sejak awal 1984, Indonesia telah melakukan reformasi perpajakan dari yang semula didominasi government/official assessment system berpindah ke self assessment system. Self assessment system adalah suatu sistem pemungutan pajak yang memberi wewenang, kepercayaan, tanggung jawab kepada wajib pajak untuk menghitung, memperhitungkan, membayar, dan melaporkan sendiri besarnya pajak yang harus dibayar.

Kepatuhan memenuhi kewajiban perpajakan secara sukarela merupakan tulang punggung sistem selfassessment. Wajib pajak bertanggung jawab menetapkan sendiri kewajiban perpajakan dan kemudian secara akurat dan tepat waktu membayar dan melaporkan pajak tersebut. ${ }^{36}$

\footnotetext{
${ }^{36}$ Sony Devano dan Siti Kurnia Rahayu, Perpajakan: Konsep, Teori, dan Isu, Prenada Media Group, Jakarta, 2006.
} 
Selain kelebihan yang dimiliki, self assessment tak luput dari celah kelemahan. Celah kelemahan tersebut terletak pada sifat kesukarelaannya. Celah ini dapat dipakai oleh mereka yang tidak punya itikad baik untuk menghindar dari kewajiban pajaknya. Wajib pajak bisa saja tidak mengisi formulir tagihan pajaknya dengan benar. Celah semacam itulah yang berpeluang menimbulkan sengketa.

Sengketa pajak adalah sengketa yang timbul dalam bidang perpajakan antara wajib pajak atau penanggung pajak dengan pejabat yang berwenang sebagai akibat dikeluarkannya keputusan yang dapat diajukan banding atau gugatan kepada pengadilan pajak berdasarkan peraturan perundang-undangan perpajakan, termasuk gugatan atas pelaksanaan penagihan berdasarkan Undang-Undang Penagihan Pajak dengan Surat Paksa. ${ }^{37}$

Lembaga yang diberikan wewenang untuk menyelesaikan sengketa pajak adalah pengadilan pajak. Hal ini tertera dalam Pasal 31 ayat (1) yang berbunyi, "pengadilan pajak mempunyai tugas dan wewenang memeriksa dan memutus sengketa Pajak." pengadilan pajak memiliki kewenangan untuk memeriksa, memutus, dan mengadili sengketa pajak. Sengketa pajak itu sendiri terdiri dari sengketa pajak pusat dan sengketa pajak daerah. Termasuk pajak pusat adalah PPh, PPN dan PPNBM, PBB, BPHTB, bea materei, bea, dan cukai. Lima (5) yang pertama dikelola oleh Direktorat Jenderal Pajak, sedangkan dua lainnya ditangani oleh Direktorat Bea dan Cukai, sebagaimana diatur dalam Undang-Undang Kepabeanan Undang-Undang No. 10 tahun 1995, dan UndangUndangU Cukai No. 11 Tahun 1995.

Dalam hal kepatuhan pajak, pemerintah menerapkan beberapa kebijakan yang bertujuan untuk memastikan para wajib pajak memenuhi kewajibannya. Kebijakan tersebut diantaranya adalah pengenaan sanksi ketetapan pajak berupa Surat Tagihan Pajak/STP dan/atau Surat Ketetapan Pajak (berupa SKPKB (Surat Ketetapan Pajak Kurang Bayar/SKPKB, Surat Ketetapan Pajak Kurang Bayar Tambahan/SKPKBT), atau Surat Ketetapan Pajak Nihil/SKPN.

Selain menerapkan sanksi, pemerintah juga memberikan peluang kepada Wajib Pajak untuk melakukan upaya hukum jika mereka merasa keberatan atas ketentuan pajak tersebut. Beberapa upaya hukum yang dimungkinkan adalah;

1. Wajib Pajak dapat meminta pengurangan atas STP atau mengajukan keberatan atas SKPKB, SKPKBT dan SKPN kepada Direktur Jenderal Pajak;

${ }^{37}$ Pasal 1 ayat (5) UU Nomor 14 Tahun 2002 
2. Apabila Wajib Pajak tidak puas atas keputusan pengurangan atau keputusan keberatan, maka Wajib pajak masih mempunyai hak untuk mengajukan upaya hukum ke Pengadilan Pajak yaitu:

a. Wajib Pajak dapat mengajukan gugatan dalam hal keputusan pengurangan

b. Wajib Pajak dapat mengajukan banding ke Pengadilan Pajak atas keputusan keberatan. Dua upaya hukum tersebut juga berlaku terhadap sengketa Pajak Daerah dan Bea dan Cukai

Gugatan adalah upaya hukum yang dapat diajukan wajib pajak bila ia merasa tidak puas dengan prosedur penagihan pajak atau putusan lain di bidang perpajakan/ bea dan cukai. Sedangkan Banding adalah upaya yang dilakukan wajib pajak bila ia merasa tidak puas dengan keputusan atas keberatan yang diajukan.

\section{Peran Peradilan Pajak di tengah Globalisasi Ekonomi}

Globalisasi ekonomi, sebagaimana telah dipaparkan di muka, membuat aktivitas bisnis berlangsung dengan sangat cepat seolah tak terbatas oleh ruang dan waktu. Para pebisnis atau pelaku usaha dapat melakukan transaksi dari mana saja dan kapan saja mereka mau. Di satu sisi, kemajuan teknologi informasi dan komunikasi yang menopang globalisasi ekonomi ini sangat bermanfaat bagi para pelaku usaha untuk memulai, mempertahankan, dan bahkan mengembangkan usahanya. Namun demikian, di sisi yang lain, dukungan kemajuan teknologi informasi dan komunikasi tersebut juga dapat dimanfaatkan oleh mereka yang tidak bertanggung jawab untuk menghindar dari setiap kewajiban bisnis yang disematkan kepadanya.

Pada konteks pajak, kemajuan teknologi informasi dan komunikasi dapat dimanfaatkan oleh mereka yang 'nakal' untuk menyiasati dan menghindar dari kewajiban membayar pajak. Sebagai contoh, mudahnya memindahkan dana dari satu negara ke negara lain dalam tempo singkat sebagai konsekuensi dari ketatnya persaingan antarnegara untuk menarik investasi sebanyak-banyaknya dapat dipakai oleh para pebisnis yang berintegritas rendah untuk mengakali kewajiban pajaknya. Perilaku tidak bertanggung jawab dari para pebisnis 'nakal' itu sangat potensial menimbulkan konflik/sengketa. Jika tidak ada mekanisme baku dan terukur untuk menyelesaikan konflik/sengketa tersebut maka sama artinya dengan tidak ada keadilan dan kepastian hukum. Oleh karena itu, keberadaan sebuah institusi yang secara khusus menangani dan menyelesaikan konflik/sengketa tersebut menjadi sebuah keharusan. 
Peradilan Pajak dapat dimaknai sebagai sebuah inisiatif dan ikhtiar nyata untuk menjawab kebutuhan dan untuk beradaptasi dengan kemajuan teknologi informasi dan komunikasi di era globalisasi. Lembaga ini merupakan metamarfosa paling baru dari upaya memenuhi kebutuhan pembiayaan negara sambil memperkuat jaminan kepastian hukum. Keberadaan lembaga ini juga dapat berfungsi menetralisir unsurunsur negatif yang terkandung dalam globalisasi ekonomi.

Perpajakan merupakan salah satu hal penting di tengah globalisasi ekonomi. Selain karena terkait langsung dengan kegiatan usaha dari para pebisnis, diperlukan konsentrasi dan keahlian khusus untuk memahami dan melaksanakannya. Konsentrasi dan keahlian khusus itu dipersyaratkan mengingat banyak aspek yang bersifat teknis. Selain itu, peraturan mengenai perpajakan juga berkembang dengan sangat dinamis, dalam mana dibutuhkan konsentrasi secara khusus untuk bisa memahaminya secara benar dan komprehensif. Oleh karena itu, segala hal yang berhubungan dengan perpajakan harus dipahami secara serius dan mendetail, serta perlu perlakuan secara khusus, termasuk dalam hal Peradilan Pajak.

Terkait dengan hal tersebut, adalah tepat jika Peradilan Pajak dimasukkan dalam kategori peradilan khusus, dan tidak sekedar ad hoc. Penilaian ini didasari sejumlah alasan, antara lain pertama, perpajakan merupakan hal yang unik. Keunikan itu terletak pada substansinya yang banyak didominasi oleh aspek-aspek yang bersifat detail dan teknis. Kedua, urusan pajak merupakan sesuatu yang sangat spesifik. Dibutuhkan waktu yang relatif lama untuk memahami seluk beluknya. Oleh karena itu, adalah tepat jika pengadilan pajak mempunyai hakim sendiri yang memang sejak awal memiliki keahlian di bidang itu. Dengan demikian, waktu yang dihabiskan tidak banyak dan biaya yang dikeluarkan, untuk peningkatan kemampuan para hakim misalnya, juga bisa dihemat.

Ketiga, semangat untuk memberikan pelayanan yang sederhana, cepat dan mudah kepada masyarakat tidak akan mungkin terwujud jika, misalnya, hakim pengadilan pajak juga bertugas sebagai hakim di PTUN. Bisa dibayangkan seandainya perkara sengketa pajak yang sedang dihadapi oleh warga negara tidak masuk dalam prioritas PTUN untuk segera diselesaikan. Tentu akan lebih lama lagi waktu yang dibutuhkan untuk sampai pada penyelesaian, karena harus menunggunya masuk dalam agenda prioritas perkara di PTUN.

Keempat, cepatnya dinamika yang terjadi pada peraturan perpajakan menuntut banyak pihak, khususnya hakim, untuk juga bergerak cepat mengikuti setiap 
perkembangan yang muncul. Dalam konteks ini, sangat riskan jika hakim yang bertugas mengurus perkara perpajakan tidak mampu memfokuskan diri dan tidak mampu mengikuti perkembangan yang terus terjadi disebabkan oleh banyaknya perkara selain perkara pajak yang harus diselesaikan. Dengan kata lain, pengkhususan pengadilan pajak merupakan keputusan yang dilandasi oleh niat baik untuk mendukung terciptanya lembaga peradilan pajak yang ideal.

\section{Penutup}

Keberadaan pengadilan pajak sangat penting dalam sistem hukum Indonesia dan perekonomian global terutama jika dikaitkan dengan peran pentingnya dalam penyelenggaraan pembangunan nasional. Pengadilan pajak memberikan kepastian hukum, menciptakan rasa keadilan, dan mendukung terselenggaranya pelayanan hukum yang sederhana, cepat, dan murah.

Dengan adanya pengadilan pajak para pelaku usaha dapat memprediksi, menghitung, dan menentukan tujuan dari kegiatan usahanya. Putusan Pengadilan Pajak memuat penetapan besarnya pajak terutang dari Wajib Pajak, berupa hitungan secara teknis perpajakan, sehingga Wajib Pajak langsung memperoleh kepastian hukum tentang besarnya pajak terhutang yang dikenakan kepadanya.

Mengingat rumitnya perpajakan baik secara teoritis maupun praktis, diperlukan perlakuan khusus terhadapnya, termasuk terhadap Peradilan Pajak. Atas dasar itu maka keputusan memasukkan Peradilan Pajak dalam kategori peradilan khusus patut didukung. Terlebih, hakimnya pun tidak bersifat ad hoc, sehingga mereka bisa bekerja dengan fokus tinggi dengan dukungan pemahaman materi yang komprehensif. Dengan demikian, penyelesaian sengketa pajak dapat diselesaikan secara cepat, mudah, dan murah.

\section{Daftar Pustaka}

Adya Barata, Atep, Memahami Pengadilan Pajak "Meminimalisasi dan Menghindari Sengketa Pajak dan Bea Cukai", Elex Media Komputindo, Jakarta, 2003.

Amien Rais, M., Agenda Mendesak Bangsa Selamatkan Indonesia, PPSK Press, Yogyakarta, 2008.

Boediono, B., Perpajakan Indonesia, Jilid I, Kawula Indonesia, Jakarta, 1996. 
Devano, Sony, dan Siti Kurnia Rahayu, Perpajakan: Konsep, Teori, dan Isu, Jakarta, Prenada Media Group, 2006.

Frank, Thomas N., The New Development, Can American Law and Legal Institution Help Developing Countries?, Wisconsin Law Review, 1989.

Friedman, Thomas L., Memahami Globalisasi, Lexus dan Pohon Zaitun, Penerbit ITB, Bandung, 2002.

Ginting, Budiman, Kepastian Hukum dan Implikasinya terhadap Pertumbuhan Investasi di Indonesia, Pidato Pengukuhan Jabatan Guru Besar Tetap dalam Bidang Ilmu Hukum Investasi pada Fakultas Hukum Universitas Sumatera Utara yang disampaikan pada 20 September 2008

H.R.E. Kosasih Taruna Sepandji, MS, Konstitusi dan Kelembagaan Negara, Universal Offset, Bandung, 2002.

Hendra Halwani, R., Ekonomi Internasional dan Globalisasi Ekonomi, Jakarta, Penerbit Ghalia Indonesia, 2002.

Istiani, Nisa, Menelaah Keberadaan Pengadilan Pajak, tulisan bisa dilihat di http:/ / ww w. pemantauperadilan.com / opini / 21. MENELAAH \% 20KEBERADAAN\%20PENGADILAN\%20PAJAK.pdf

Juwana, Hikmahanto, Bunga Rampai Hukum Ekonomi dan Hukum Internasional, Lentera Hati, Jakarta, 2002.

Arah Kebijakan Pembangunan Hukum di Bidang Perekonomian dan Investasi, dalam: Majalah Hukum Nasional, No. 1 Tahun 2007, BPHN, Departemen Hukum dan HAM RI.

K. Dhaniswara, Harjono, Hukum Penanaman Modal: Tinjauan Terhadap Pemberlakuan Undang-Undang Penanaman Modal, Raja Grafindo Persada, Jakarta, 2007.

Muchsin, Kekuasaan Kehakiman yang Merdeka \& Kebijakan Asasi, Depok, STIH "Iblam", 2004.

Rajagukguk, Erman, Peranan Hukum dalam Pembangunan Ekonomi, Jilid 2, Universitas Indonesia, Jakarta, 1995.

Ryaas Rasyid, Muhammad, Makna Pemerintahan Tinjauan dari segi Etika dan Kepemimpinan, Jakarta, PT. Mutiara Sumber Widya Penabur Benih Kecerdasan, 2002.

Suhardi, Gunarto, Peranan Hukum Dalam Pembangunan Ekonomi, Universitas Atmajaya, Yogyakarta, 2002.

Tambunan, Tulus, Implikasi dari Globalisasi/Perdagangan Bebas Dunia terhadap Ekonomi Nasional, Makalah disampaikan dalam Seminar Penataan Ruang dan Pengembangan Wilayah, Dep.PU, Jakarta, 1 Juli 2005

UU Nomor 6 Tahun 1983 tentang Ketentuan Umum dan Tata Cara Perpajakan sebagaimana telah diubah terakhir dengan UU Nomor 28 Tahun 2007

UU Nomor 14 Tahun 2002

www.infed.org/biblio/defining-globalization.htm 
Tjip Ismail. Peradilan Pajak dan... 293

www.fiskal.depkeu.go.id

www.worldbank.org/economic policy/globalization/ag 01.htm, The World Bank Group, Globalization 
